\title{
Model structure and analysis of dimethylsulphide (DMS) production in the southern North Sea, considering phytoplankton dimethylsulphoniopropionate- (DMSP) lyase and eutrophication effects
}

\author{
A. J. van den Berg ${ }^{1, *}$, S. M. Turner ${ }^{2}$, F. C. van Duyl ${ }^{1}$, P. Ruardij $^{1}$ \\ 'NIOZ, Netherlands Institute for Sea Research, PO Box 59, 1790 AB Den Burg, The Netherlands \\ ${ }^{2}$ School of Environmental Sciences, University of East Anglia, Norwich NR4 7JT, United Kingdom
}

\begin{abstract}
A model for dimethylsulphide (DMS) production in the southern North Sea is presented. This model is coupled to the phytoplankton model FYFY, which calculates the biomass of different phytoplankton groups with their specific contents of dimethylsulphoniopropionate (DMSP), the precursor of DMS. The combined models provide a synoptic view of the seasonal distribution of DMS and its sea-to-air exchange rates. Results are in close agreement with field data, showing a spring peak and high concentrations in the coastal area off continental Europe. Model analysis shows high sensitivity to phytoplankton DMSP-lyase, particularly in the description of the spring peak of DMS. Omission of this pathway for DMS production leads to an underestimation of the annual sea-to-air flux of up to $25 \%$. Model output also suggests that anthropogenic eutrophication of the southern North Sea may have caused a 2.5 -fold increase between the beginning of this century and the 1980s in the mean annual emission of DMS to the atmosphere.
\end{abstract}

KEY WORDS: Dimethylsulphide (DMS) · Dimethylsulphoniopropionate (DMSP) · Phytoplankton DMSP-lyase - DMSP content - DMS model

\section{INTRODUCTION}

Dimethylsulphide (DMS) is a very important trace gas in the global sulphur cycle. It is produced in seawater by several classes of phytoplankton (Turner et al. 1988, Keller et al. 1989), and a fraction is emitted to the atmosphere. Here, DMS is oxidised to products such as sulphur dioxide and sulphate, which contribute to atmospheric acidity and aerosols, including cloud condensation nuclei (Charlson et al. 1987, Ayers 1991). Thus, DMS may play an important role in climate regulation, via modulation of global albedo. Further, it has been suggested that global warming, through the

•E-mail: rua@nioz.nl 'greenhouse effect' for example, may increase the flux of DMS to the atmosphere (Charlson et al. 1987, Gabric et al. 1993). It is thus of great interest to know more about the processes of DMS production and the way they are influenced by human activity. In addition to global warming, other processes such as coastal eutrophication might influence DMS production through an increase in phytoplankton biomass, which can include a shift in species and selective changes in biomass (Cadée 1990). The latter is of particular significance since it is generally accepted that most DMS originates from dimethylsulphoniopropionate (DMSP), which is produced in varying quantities by different phytoplankton species (Matrai \& Keller 1994, Wolfe et al. 1994). However, the pathways for DMS production and their relative importance and effect on sea-to-air fluxes are poorly understood. In the model presented here, 
we describe the processes mathematically. We attempt to fill in the 'black box' and to assess the consequences of the underlying assumptions, like the DMSP contents, the grazing characteristics, etc. Special attention is given to 2 factors which are important for DMS production and which are species specific: firstly, DMSP content and release from cells; and, secondly, algal lyase, which has been recognised as important in the degradation of DMSP to DMS (Stefels \& van Boekel 1993). The model described here is the first to give a synoptic view of DMS concentration and dynamics in the southern North Sea. Earlier models, such as that of Gabric et al. (1993), only cover the spring peak dynamics or do not consider DMS production rates in the calculation of sea-to-air fluxes (Lawrence 1993). However, all these processes mutually interact and should be integrated in a comprehensive study. Results of field data from the southern North Sea show that there are large temporal and spatial variations in DMS concentrations and fluxes (Liss et al. 1993, Turner et al. 1996). This data set is used to examine the extent to which the model assumptions can reproduce the temporal and spatial variance

\section{THE MODEL}

The model is a combination of the phytoplankton model FYFY described in van den Berg et al. (1996) and a new model for DMS production. Although the models are linked, they do not interact with each other. The phytoplankton model provides input to the DMS model in the form of DMSP production rates and phytoplankton and bacterial biomass. Further, it provides a spatial basis for the DMS model.

Phytoplankton model FYFY. The structure of the biological model is shown in Fig. 1. A full description of the model is given in van den Berg et al. (1996) and a brief outline is given below.

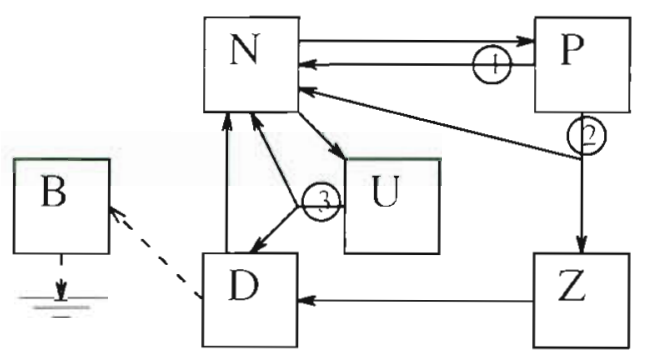

Fig. 1. Structure of the biological part of the FYFY model (van den Berg et al. 1996). $N=$ Nutrient; $P=$ Grazed algae; $U=$ Ungrazed algae $;=$ Zooplankton $; \mathbb{D}=$ Detritus $; \mathrm{B}=$ Bacteria . (1). (2) and (3) are fluxes where DMSP is produced. (1) and (3) are lysis rates and (2) is the zooplankton grazing rate
The phytoplankton model describes the growth and interaction between zooplankton and 6 functional groups of phytoplankton. The functional groups differ only in the parameter settings, which reflect their ecological properties. The physiological mechanisms, however, are identical for all groups. Dissolved nitrogen (ammonium and nitrate), phosphorus and silicon are taken up by the phytoplankton, the latter nutrient only by diatoms. Three of the 6 groups of phytoplankton are grazed by zooplankton. For reasons of simplicity we assume that the grazing on poorly edible phytoplankton is negligible; hence the other 3 groups of phytoplankton are not grazed. Dead biological matter becomes detritus that is mineralised to dissolved inorganic nutrients. Carbon is respired by bacteria at a temperature-dependent rate proportional to the concentration of detritus. The model covers the southern part of the North Sea and the grid size is $22.450 \times 22.450 \mathrm{~km}^{2}$. The FYFY model is bounded to the south by the English Channel and to the north by the line of $54^{\circ} \mathrm{N}$ latitude. The nutrient inputs from the rivers are for 1987, data which were collected and processed for the North Sea Task Force modelling workshop by Rijkswaterstaat of the Dutch Ministry of Transport, Public Works and Water Management, The Hague, The Netherlands (unpubl data). The natural background concentrations were also processed by Rijkswaterstaat of the Dutch Ministry of Transport, Public Works and Water Management with concentrations before 1940 (unpubl. data) Natural. background concentrations are calculated to be $12 \%$ of the river nutrient concentrations of 1987 for nitrogen and phosphorus and $133 \%$ of the concentrations of 1987 for silicon. Forcing functions in the model are the incident irradiance, the water temperature and the suspended particulate matter concentrations. Irradiance is taken from the meteorological station 'de Kooy' in Den Helder, The Netherlands, for 1985. Water temperature is assumed to be a sine curve in time with a minimum at 10 February. Minimum and maximum values vary from 4 to $17^{\circ} \mathrm{C}$ near the coast to 5.5 to $16.5^{\circ} \mathrm{C}$ offshore. Winter concentrations of suspended particulate matter are shown in Fig 2 and range from $36 \mathrm{~g} \mathrm{~m}^{-3}$ close to the coast to $3 \mathrm{~g} \mathrm{~m}^{-3}$ near the central North Sea. These winter concentrations are a compilation of data from several sources, i.e. Dyer \& Moffat (1993) with data from NERC (1989). Eisma (1981) and NOAA satelite images from the KNMI (1991), and reflect the general pattern of suspended particulate matter concentrations in the southern North Sea. In summer, the concentrations are lowest and a sine curve in time with constant amplitude and segment specific average is used to calculate the concentrations throughout the year. The spatial segments are shown in Fig 2. Sus- 


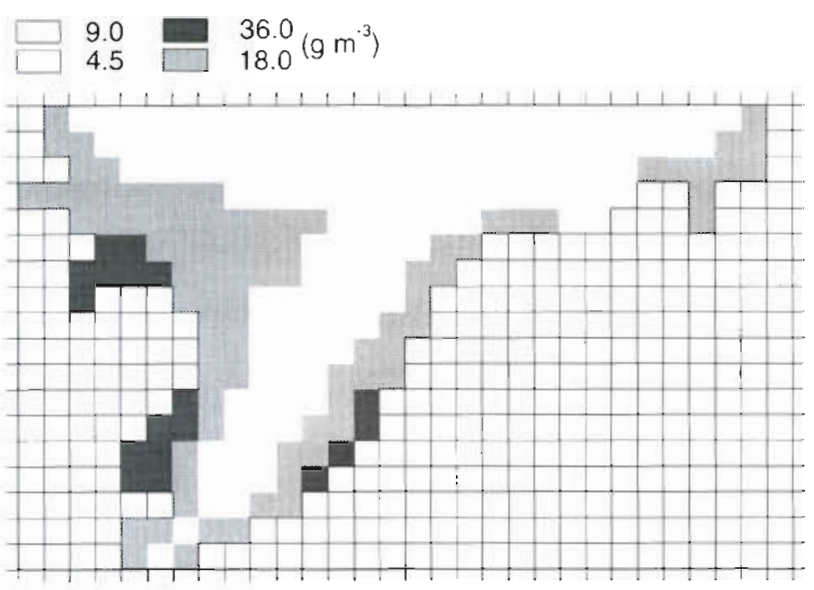

Fig. 2. Suspended particulate matter concentration in winter (g $\mathrm{m}^{-3}$ ). Data from Dyer \& Moffat (1993). Eisma (1981) and NOAA satellite images from the KNMI (1991)

pended particulate matter influences the underwater light climate in the model.

DMS model. DMSP production and release from algal cells: Production: DMSP is produced in algal cells and is assumed to be proportional to the phytoplankton biomass. However, since intracellular levels of DMSP differ between species (Andreae et al. 1983, Keller et al. 1989, Malin et al. 1993), a measure of this variability must be incorporated in the model to give a more accurate description of production. The phytoplankton populations of the southern North Sea are often dominated by Phaeocystis sp., and in some areas more than $50 \%$ of the annual primary productivity is attributed to this genus (Fransz \& Gieskes 1984, Lancelot \& Billen 1984). Phaeocystis $\mathrm{sp}$. has a notably high DMSP content which is about 6 times higher than that of diatoms and other species (Stefels \& van Boekel 1993, Liss et al. 1994). It is shown by Hansen et al. $(1991,1993)$ that Phaeocystis $\mathrm{sp}$. is hardly grazed in natural systems. Furthermore, the colony form is less edible to a variety of grazers than the flagellate stage (Weisse \& Scheffelmöser 1990), and Estep et al. (1990) show that healthy Phaeocystis colonies are not consumed by copepods. Therefore, this species is best described by the functional groups of ungrazed flagellates that reflect these features in the FYFY model (van den Berg et al. 1996). Although colonies in poor condition are susceptible to grazing (Estep et al. 1990), this grazing does not exhibit the same functionality as is incorporated in the FYFY model. Grazing can only limit the population levels when it acts on viable cells which otherwise would grow ad libitum. The DMSP contents of the functional groups of ungrazed flagellates in the model, therefore, are assumed to be higher than the DMSP contents of the diatom and grazed flagellates groups; this reflects the variability in accordance with the results of Stefels \& van Boekel (1993) and Liss et al. (1994).

Release: DMSP is released upon lysis and disintegration of the phytoplankton cells. This is proportional to the lysis rate of the species (see Eq. 3). The sedimentation characteristics of the ungrazed groups are such that only $80 \%$ of the lysis process and DMSP release takes place in the pelagic zone. The remaining $20 \%$ of the DMSP released is lost to the sediment.

Phytoplankton cells are also disrupted by zooplankton grazing (see Eq. 3) (Dacey \& Wakeham 1986, Belviso et al. 1990, Leck et al. 1990). Some zooplankton species, however, ingest the cells and the DMSP is lost in decomposition processes in the guts (Wolfe et al. 1994, Kwint et al. 1996). In view of the schematical functional plankton groups in the model, it is difficult to decide which kind of grazing is most important, so the model accounts for both processes equally.

Conversion of DMSP and production of DMS: BaCteria: DMSP conversion is mediated by bacterial enzymes through cleavage and demethylation. In the process of DMSP cleavage, DMS and acrylate are formed (Challenger 1959, Dacey \& Blough 1987, Kiene 1990, Kiene \& Service 1991). DMSP is demethylated by bacteria with 3-methiolpropionate as an intermediate (Taylor \& Gilchrist 1991, Visscher et al. 1992). In this process, no DMS is formed. Demethylation accounts for about $70 \%$ of the total conversion of DMSP (Kiene $\&$ Service 1991). Both rates are proportional to the DMSP concentration and the total bacterial population (see Eq. 1).

Phytoplankton lyase: DMSP is also broken down by phytoplankton lyase (see Eq. 1) (Cantoni \& Anderson 1956, Ishida 1968, Stefels \& van Boekel 1993). In this process, DMS is produced. This lyase is produced by the algal species with high DMSP production and is proportional to their biomass. The Michaelis-Menten kinetics, i.e. DMSP $/\left(K_{m}+\right.$ DMSP $)$, is a hyperbolic relationship. It approaches linearity when DMSP concentrations are low. This is because in the latter case (DMSP $+K_{\mathrm{m}}$ ) approaches $K_{\mathrm{m}}$. So, the kinetics of the lyase can be described by a linear relation, since the concentrations of DMSP in the field are low (Stefels \& van Boekel 1993). Thus the conversion rate is proportional to the DMSP concentration and the impartant DMSP producing phytoplankton species, i.e. the ungrazed flagellates.

Loss processes of DMS: There are 2 loss processes of DMS. The first is bacterial uptake (Taylor \& Kiene 1989, Kiene \& Bates 1990, Kiene 1992). This is proportional to the DMS and bacterial concentrations (see Eq. 2). The second process is DMS emission to the atmosphere (Liss \& Slater 1974). This flow is dependent on the DMS concentration in the water at the seaair interface. The sea-air exchange coefficient is a function of the diffusivity of DMS, water temperature 
and wind speed. The model incorporates linearly interpolated wind forcing throughout the year, based on measured data at $110 \mathrm{~km}$ west of Texel, The Netherlands, $53^{\circ} 10^{\prime}$ to $53^{\circ} 20^{\prime} \mathrm{N}, 3^{\circ}$ to $3^{\circ} 10^{\prime} \mathrm{E}$, in 1989 . The coefficient is calculated according to Turner et al. (1996). For comparison of the loss processes, Kiene \& Bates (1990) found that bacterial consumption is more than 10 times higher than the sea-to-air flux.

Structure: The structure of the DMS model is shown in Fig. 3 and mathematically described with the follow. ing set of differential equations:

$$
\begin{gathered}
\frac{\mathrm{d} D 1}{\mathrm{~d} t}=f-k_{2} B D 1-k_{3} F I_{\mathrm{u}} D 1-k_{4} B D 1 \\
\frac{\mathrm{d} D 2}{\mathrm{~d} t}=k_{3} F l_{\mathrm{u}} D 1+k_{4} B D 1-\frac{k_{5}}{z} D 2-k_{6} B D 2 \\
f=q_{\mathrm{gll}}(1)+q_{\mathrm{gfl}} p_{1}(2)+q_{\mathrm{ufl}} p_{2}(3)
\end{gathered}
$$

D1 and D2 are, respectively, DMSP and DMS in nmol $l^{-1}$. $F l_{u}$ is ungrazed flagellate species and $B$ is bacteria, both in $\mathrm{mg} \mathrm{m}^{-3} . z$ is the depth of the water column. $f$ is the DMSP release rate from the fluxes (1), (2) and (3) (see Fig 1). Fluxes (1) and (3) represent the lysis rate of the phytoplankton and flux (2) the grazing rate of the zooplankton. DMSP is released at a rate proportional to these processes. The parameter $k_{2}$ is the bacterial demethylation rate constant, $k_{3}$ is the lyase activity, $k_{4}$ is the bacterial cleavage and $k_{5}$ is the bacterial uptake constant, all in $\mathrm{m}^{3} \mathrm{mg}^{-1} \mathrm{~d}^{-1} . k_{5}$ is the sea-air exchange parameter in $\mathrm{m} \mathrm{d}^{-1}$. The parameters $p_{1}$ and $p_{2}$ are the percentages of the grazing rate and lysis rate, respectively, of ungrazed species effectively releasing DMSP. The DMSP in the remainder of these rates is lost from the system to sedimentation or consumption. The quotas $q_{\text {gfl }}$ and $q_{\text {ufl }}$ are the DMSP contents per phytoplankton biomass of grazed and ungrazed species, respectively.

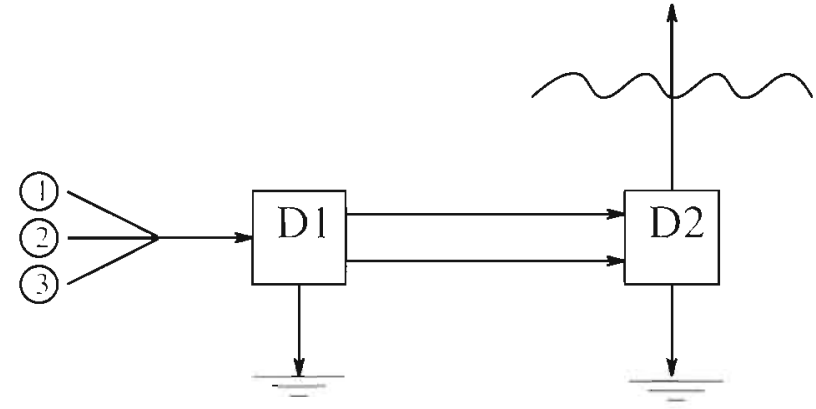

Fig. 3. Structure of the DMS model. $D 1=$ DMSP, $D 2=$ DMS. (1). (2) and (3) are the DMSP production rates from the fluxes as shown in Fig. 1

Table 1 lists the values of the parameters used in the DMS model.

Steady state: The DMS model is analysed by calculating the steady-state values of the state variables, assuming the system to be in pseudo equilibrium with the seasonal changes in light and temperature. Substituting $d / d t=0$ into Eqs. (1) \& (2) and rearranging gives:

$$
\begin{gathered}
\tilde{D} 1=\frac{f}{k_{2} B+k_{4} B+k_{3} F I_{u}} \\
\tilde{D} 2=\frac{f\left(k_{4} B+k_{3} F l_{u}\right)}{\left(\frac{k_{5}}{z}+k_{6} B\right)\left(k_{2} B+k_{4} B+k_{3} F l_{u}\right)}
\end{gathered}
$$

The steady state is most likely to be approached during the summer after the spring bloom, when there are no major changes in physical circumstances. The biomass of the bacteria and ungrazed flagellates is imposed by the phytoplankton model. The DMSP concentration is averaged from field studies in coastal areas (Wakeham et al. 1987, Turner et al. 1988, Iverson et al. 1989, Belviso et

\begin{tabular}{|c|c|c|c|c|c|}
\hline \multirow[t]{2}{*}{ Parameters } & & \multirow{2}{*}{$\begin{array}{c}\text { DMS model } \\
\text { A }\end{array}$} & \multicolumn{2}{|c|}{ Model variations } & \multirow[t]{2}{*}{ Units } \\
\hline & & & $\mathrm{B}$ & $c$ & \\
\hline \multicolumn{6}{|l|}{ DMSP quotum } \\
\hline Diatoms & $q_{d}$ & 0.15 & - & - & $\mathrm{nmol} \mathrm{mg}^{-1}$ \\
\hline \multicolumn{6}{|l|}{ Flagellates } \\
\hline Grazed & $q_{\text {gfl }}$ & 0.15 & 0.90 & - & $\mathrm{nmol} \mathrm{mg} \mathrm{m}^{-1}$ \\
\hline Ungrazed & $q_{\text {ufl }}$ & 0.90 & 0.15 & - & $\mathrm{nmol} \mathrm{mg^{-1 }}$ \\
\hline Grazing prod. percentage & $p_{1}$ & 50 & - & - & $\%$ \\
\hline Lysis prod. percentage & $p_{2}$ & 80 & - & - & $\%$ \\
\hline Bacterial demethylation constant & $k_{2}$ & $3.67 \times 10^{-3}$ & - & - & $\mathrm{m}^{3} \mathrm{mg}^{-1} \mathrm{~d}^{-1}$ \\
\hline Lyase activity constant & $k_{3}$ & $0.26 \times 10^{-3}$ & - & 0.00 & $\mathrm{~m}^{3} \mathrm{mg}^{-1} \mathrm{~d}^{-1}$ \\
\hline Bacterial cleavage constant & $k_{4}$ & $0.79 \times 10^{-\ldots}$ & - & $1.58 \times 10^{-3}$ & $\mathrm{~m}^{3} \mathrm{mg}^{-1} \mathrm{~d}^{-1}$ \\
\hline Sea-air exchange constant & $k_{5}$ & 3.70 & - & - & $\mathrm{m} \mathrm{d}^{-1}$ \\
\hline Bacterial uptake constant & $k_{6}$ & $17.74 \times 10^{-3}$ & - & - & $m^{3} \mathrm{mg}^{-1} \mathrm{~d}^{-1}$ \\
\hline
\end{tabular}
al. 1990). The DMS concentration is 10 to 20 times lower

Table 1. DMS model parameters. A: DMS model. B: model variation with grazed flagellates functional groups representing species with high DMSP content. C: model variation with deactivated lyase activity. Only modified parameters of comparative models are indicated (see text for a full description of the parameters) 
in these areas (Turner et al. 1988, Cooper \& Matrai 1989, Andreae 1990, Leck \& Rodhe 1991). With these concentrations and equations the model parameters can be estimated, considering flow measurements in the field and experimental parameter values.

DMS model variations. Two variations of the model, model variations $B$ and $C$ in Table 1 , are used to simulate the consequences of some of the assumptions in the DMS model. In model variation $B$, the functional groups of grazed flagellates are allocated high DMSP instead of the ungrazed flagellates in order to test if distinction between these groups is meaningful. In model variation $C$, the phytoplankton lyase activity is deactivated to estimate the importance of this process in the efflux of DMS to the air. The bacterial cleavage constant is increased to balance the steady-state equations in the relatively stable open sea region. The model was also used to assess the impact of eutrophication of the North Sea on DMS fluxes by employing a simulation without anthropogenic nutrient input from the rivers. Natural background concentrations were estimated and calculated by Rijkswaterstat of the Dutch Ministry of Transport, Public Works and Water Management, The Hague (unpubl. data).

\section{RESULTS}

\section{DMS concentration}

The model is simulated with standard parameter settings (Table 1) until a stable yearly cycle is reached. The model dynamics of the DMS concentration in the southern North Sea follow a seasonal cycle that is comparable to the phytoplankton dynamics in the model with a time delay of about 1 or 2 wk (results not showny. In spring, there is a distinct peak in the concentrations. After this, DMS reaches its constant summer levels, while in winter it becomes very low. In Fig. 4, the mean DMS concentrations from February to October are compared with field data for the Southern North Sea from Turner et al. (1996)

The field data were collected at the beginning of each month, so the mean DMS concentrations of the model were calculated for the same period in the simulation. The observational data are very well described by the model simulation with a mean summer concentration of $5 \mathrm{nmol}^{-1}$. The spring peak is adequately reproduced, although the timing is 1 or 2 wk too early. The summer concentrations and dynamics are within the field limits. In autumn, however, the model concentrations do not decrease in time and remain too high for the last $1 \frac{1}{2}$ mo. In Fig. 5, the spatial development in time of the DMS concentration is compared to interpolated field data from Turner et al. (1996).

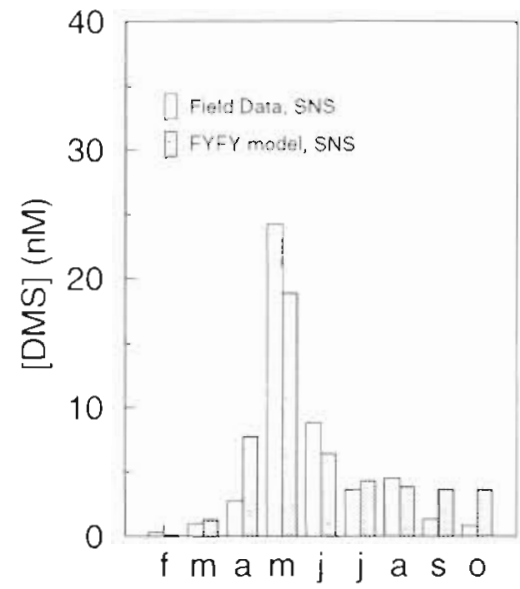

Fig. 4. Comparison of monthly mean DMS concentrations of field data and DMS model results in nmol $\mathrm{l}^{-1}$. Field data for 1989 were collected at the beginning of each month by Turner et al. (1966) in the southern North Sea (SNS), so model results were calculated for the same period and region

The DMS peak in the model starts in the northeastern part of the southern North Sea near the German Bight in April. It spreads along the Dutch coast and is highest in May in concordance with the field data. In June, the concentration spreads toward the United Kingdom, as was also observed in the field. However, the high concentrations in the channel region are not described by the FYFY model. In July, the concentrations are highest near the Dutch coast. In September, they start to decrease. In October, DMS is still present in the FYFY model, while the concentrations in the field are already low.

\section{Sea-air exchange}

The flux of DMS in the model from sea to air is shown in Fig. 6. The temporal and spatial patterns of the flux follow the dynamics of the DMS concentration in the model, which were shown before in Fig. 4.

The DMS sea-to-air exchange rate calculated by the model is within the range of literature data from the field (Table 2).

\section{Lyase activity}

DMS production by phytoplankton lyase in the model is highest in the coastal region and in the spring bloom period as shown in Table 3. Furthermore, the contribution of the lyase activity to the total conversion flow is highest in the spring peak and relatively large in the coastal region (percentages in parentheses in Table 3). 

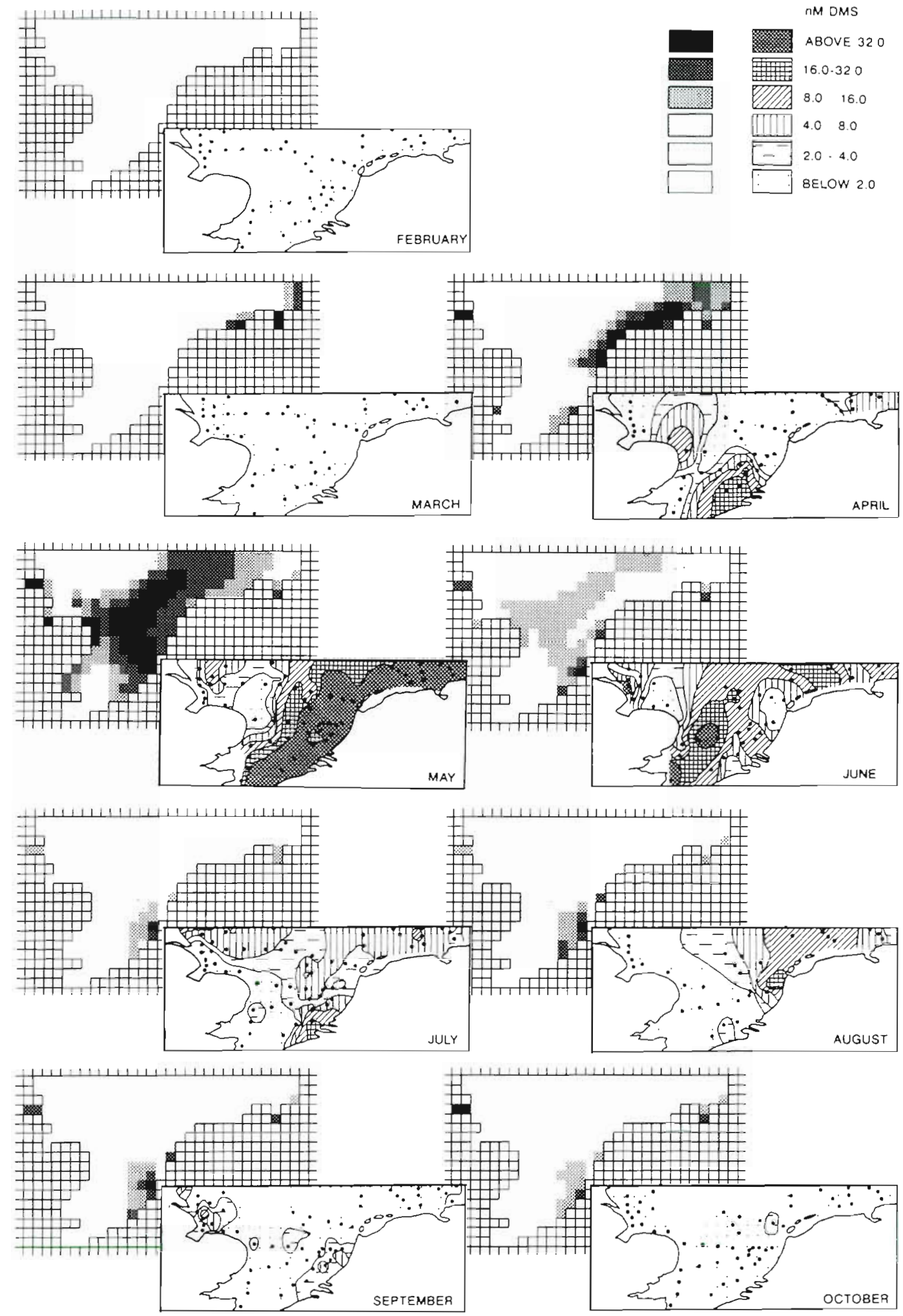

Fig. 5. Companson of mean DMS concentrations at the beginning of the month: field data (overlay) and DMS model (grid) results in nmol $\mathrm{l}^{-1}$. Field data were collected by Turner et al. (1996) from February to October 1989 


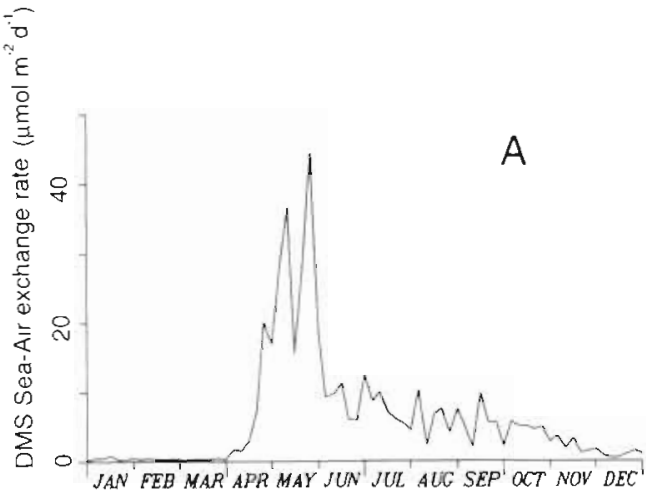

Fig. 6. Sea to air exchange rate of DMS in the model in $\mu \mathrm{mol} \mathrm{m}^{-2} \mathrm{~d}^{-1}$ (A) Temporal representation of the open sea region. (B) Spatial distribution of the mean DMS concentration at the beginning of the month

\section{Importance of the lyase activity process}

In Table 4, DMS production in the model is compared to production without lyase activity (model variation $C$ ) to see if phytoplankton lyase is of any importance for DMS production.

DMS production with lyase activity is twice as high during the spring peak, while the flux from sea to air is $2 \frac{1}{2}$ times higher. In the summer period, incorporation of the process of lyase activity is of minor importance for predicting the flow. On a yearly basis, both DMS production and flux from sea to air are $25 \%$ higher in the southern North Sea when lyase activity is present.

\section{Eutrophication}

Results of model simulations with only natural, background nutrient inputs show that anthropogenic riverine inputs induce higher DMS concentrations throughout the southern North Sea. Table 5 describes the enhancement in DMS due to anthropogenic nutrients for different areas and seasons. Increase in DMIS concentration is particularly marked during the spring bloom and there is a much greater effect in the coastal areas (Table 5). The same pattern is seen for DMS fluxes, and during the spring peak the enhancement of flux is equivalent to that of DMS concentration. When calculations include the anthropogenic input of the 1980s, the yearly DMS flux from sea to air in the southern North

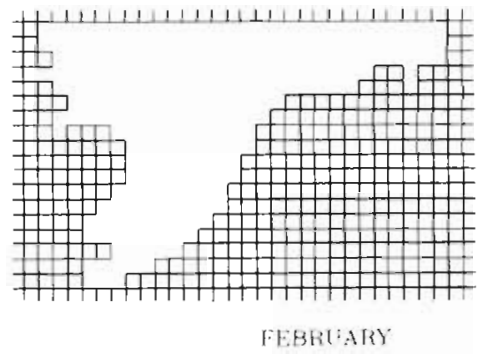

B DMS Sea-Air exchange rate $\mu \mathrm{mol} \mathrm{m}^{2} \mathrm{~d}^{\prime \prime}$

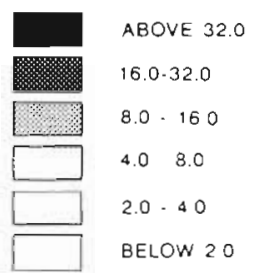

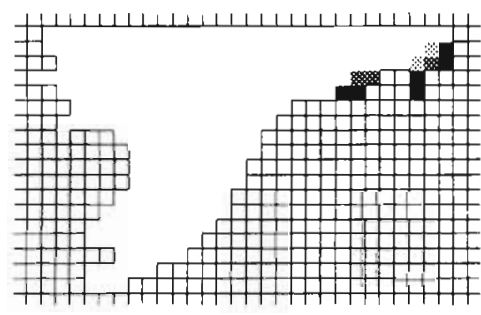

MARC'H

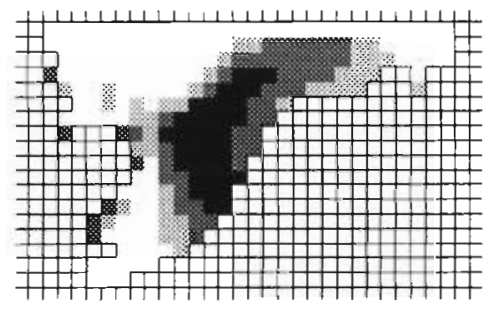

MiY

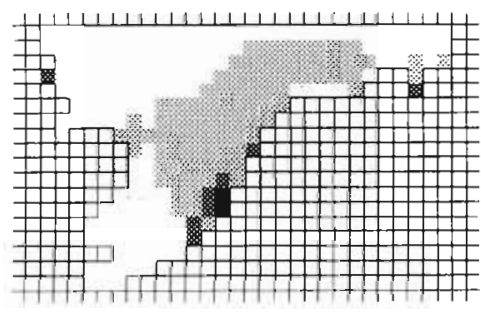

JIX

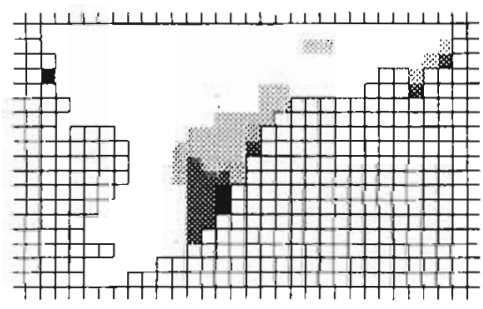

SEPTEMBER

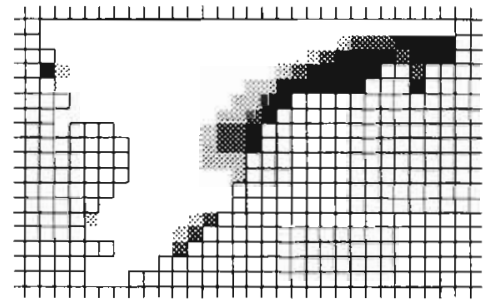

BPRIL

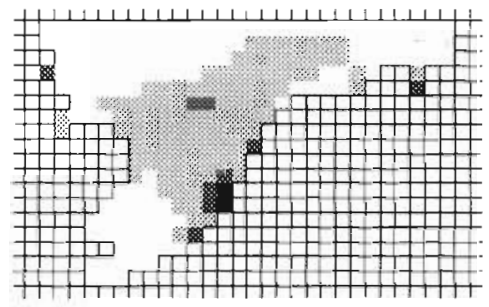

$\operatorname{ll} N$

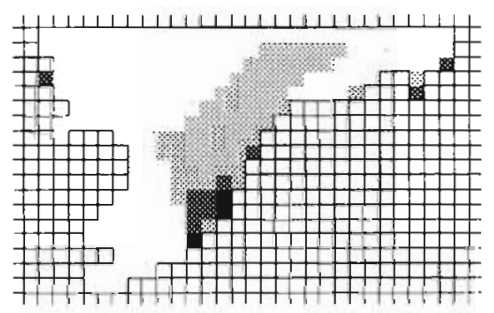

ALGIST

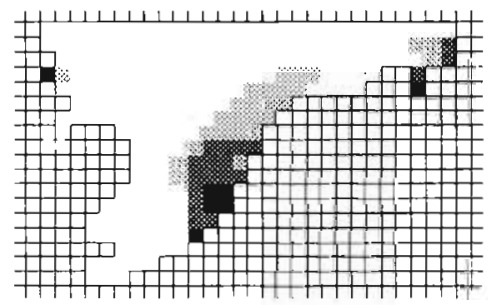

OC"TOBFR
Sea as a whole is $2 \frac{1}{2}$ times higher than it was at the start of this century. However, eutrophication has been gradually decreasing in the 1990s, so nowadays the flux will be somewhat lower. 
Table 2. Ranges of DMS sea-air exchange fluxes from different sources

\begin{tabular}{|c|c|c|c|}
\hline Source & Flux $\left(\mu \mathrm{mol} \mathrm{m}^{-2} \mathrm{~d}^{-1}\right)$ & Region & Period \\
\hline The model & $7-40$ & Southern North Sea & Yedr \\
\hline Liss et al. (1993) & $2-16$ & Southern North Sea & February-October \\
\hline Turner et al. (1988) & 31 & Southern North Sea & Summer \\
\hline Malin et al. (1993) & 16 & Southern North Sea & Summer \\
\hline Stefels et al. (1995) & 17 & Dutch coast & Spring bloom \\
\hline Kiene \& Bates (1990) & $0-36$ & Eastern tropical Pacific Ocean & February \\
\hline Brimblecombe (1989) & 11 & Global & Year \\
\hline
\end{tabular}

Table 3. Mean DMS production rates by lyase activity per region and per period $\left(\mu \mathrm{mol} \mathrm{l}^{-1} \mathrm{~d}^{-4}\right)$. The spring peak period is from April to mid May and the summer period is June and July. Percentages of the total DMS production are shown in parentheses

\begin{tabular}{|lcc|}
\hline & Open sea region & Coastal region \\
\hline Spring peak & $4.2(86 \%)$ & $16.4(85 \%)$ \\
Summer & $0.8(47 \%)$ & $6.7(68 \%)$ \\
\hline
\end{tabular}

Table 4. DMS production and flux of DMS from sea to air in the model as percentage of the production without lyase activity

\begin{tabular}{|c|c|c|c|}
\hline & $\begin{array}{l}\text { Open sea } \\
\text { region }\end{array}$ & $\begin{array}{l}\text { Coastal } \\
\text { region }\end{array}$ & $\begin{array}{l}\text { Southern } \\
\text { North Sea }\end{array}$ \\
\hline \multicolumn{4}{|c|}{ DMS production } \\
\hline Spring peak & $258 \%$ & $204 \%$ & $200 \%$ \\
\hline Summer & $85 \%$ & $134 \%$ & $100 \%$ \\
\hline Year & & & $125 \%$ \\
\hline \multicolumn{4}{|c|}{ Flux DMS to air } \\
\hline Spring peak & $291 \%$ & $260 \%$ & $238 \%$ \\
\hline Summer & $87 \%$ & $129 \%$ & $94 \%$ \\
\hline Year & & & $124 \%$ \\
\hline
\end{tabular}

Table 5. DMS production and flux of DMS from sea to air in the model as percentage of the production without anthropogenic nutrient input

\begin{tabular}{|lccc|}
\hline & $\begin{array}{c}\text { Open sea } \\
\text { region }\end{array}$ & $\begin{array}{c}\text { Coastal } \\
\text { region }\end{array}$ & $\begin{array}{c}\text { Southern } \\
\text { North Sea }\end{array}$ \\
\hline $\begin{array}{l}\text { DMS production } \\
\text { Spring peak }\end{array}$ & $258 \%$ & $970 \%$ & $357 \%$ \\
Summer & $189 \%$ & $980 \%$ & $286 \%$ \\
Year & & & $375 \%$ \\
Flux DMS to air & & $658 \%$ & $355 \%$ \\
Spring peak & $225 \%$ & $458 \%$ & $197 \%$ \\
Summer & $151 \%$ & & $268 \%$ \\
Year & & & \\
\hline
\end{tabular}

\section{DMSP producing species}

Fig. 7 gives a comparison of the averages of modelled and field data for the cases where ungrazed functional groups are allocated high DMSP (Fig. 7A) and where the grazed group has high DMSP (Fig. 7B). The results clearly show that the 2 scenarios produce very different DMS concentrations and that this difference is particularly marked during the spring peak.

Fig. 8 shows the modelled spatial distributions of DMS for the grazed functional group having high DMSP (model variation $B$ ); it also shows the comparative field data. In this case, it is clear that the bloom not only starts too late but also that it is initiated near the Channel instead of the Dutch coast and German Bight. Furthermore, the concentrations in summer are lowest near the Dutch coast, whereas they are highest in the field. Therefore, field data are far better reproduced by attributing high DMSP to the ungrazed functional group (see Fig 5).

\section{DISCUSSION AND CONCLUSIONS}

The DMS concentrations generated by the model are in good agreement with the field data, both spatially and temporally. The modelled higher concentrations in September and October are caused by the phytoplankton dynamics which are not adequately described by the FYFY model (van den Berg et al. 1996). The growing season appears to last too long in comparison to field data (Turner et al. 1996), which might be caused by a lack of autumn storm events in the model. These storms enhance the phytoplankton growth temporarily after which the algal biomass collapses and the productive season comes to an end. A correction of the phytoplankton dynamics in the model will lead to a better description of the DMS concentrations. The high DMS concentrations in the Channel region that were found in the field in 1989 (Turner et al. 1996) were also related to high phytoplankton concentrations measured as chlorophyll by Joint \& Pomroy (1993). These high concentrations are not described by the FYFY 
model and there are 2 possible causes. Firstly, there may be an underestimation of the Channel boundary conditions for 1989, since the FYFY model uses mean values over several years. Secondly, the flow fields for 1979 instead of those for 1989 are used, which might influence the distribution and import of phytoplankton in this region. The DMS seaair flux in the model is highest in the spring bloom period. whereas Turner et al. (1996) calculate fluxes that are highest in the summer. These differences are mainly caused by the values of the wind speeds used to calculate the exchange coefficients. Local and temporal disparity in wind speed probably accounts for these different dynamics.

The model description of the phytoplankton functional groups produces a good simulation of the spatial and temporal variation in DMS when high DMSP and DMSP-lyase are allocated to the ungrazed phytoplankton. This group occurs mainly in the continental coastal area and produces a distinct spring peak. When DMSPlyase activity is disabled in the model simulation, bacterial conversion of DMSP is the only process for DMS production. Field observations show that bacterial concentrations are low during the spring bloom (Billen \& Fontigny 1987, Billen et al. 1990, Boekel et al. 1992, Brussaard et al. 1995). This is also the case in the model, since bacterial growth is limited by the time lag in production of detritus and the slow rate of degradation of the detritus on which they grow. When bacterial conversion of DMSP is the only pathway for DMS production, results do not compare favourably with the measured data, particularly during the spring bloom. There is an underestimation of DMS concentration, which is reflected in the sea-to-air flux. On an annual basis, the flux from the southern North Sea is underestimated up to $25 \%$. The laboratory studies of Stefels \& van Boekel (1993) suggest that algal lyases are an important pathway for DMS production and the model results appear to support this.

The results from model variation $B$, where the grazed functional groups were allocated high DMSP, showed that there was poor representation of the spatial and temporal distributions of DMS. This shows that the grazed phytoplankton cannot be the sole functional group with high DMSP production and contents. The assumption that Phaeocystis sp. is best described by the ungrazed functional groups (as discussed in 'The model: DMS model') is not contradicted by field observations of DMS concentrations. It cannot be concluded from the DMS distribution that Phaeocystis sp. must be a species belonging to the ungrazed functional groups in the FYFY model when there are other spe- cies, grazed or ungrazed, which have the same high DMSP content as Phaeocystis sp. However, if Phaeocystis sp. does indeed have a much higher DMSP content than other relevant species in the southern North Sea, it cannot be described by the grazed functional groups in the FYFY model, but has to be described by the ungrazed groups in order to give a good description of the field data. The latter conforms to the observations that Phaeocystis sp is poorly grazed (as discussed in 'The model: DMS model').

Model results suggest that anthropogenic nutrient input to the southern North Sea has had a significant effect on DMS production and flux. The nutrients are discharged along the coast and the largest increase in phytoplankton biomass occurs in the coastal zone, particularly along the continental coast. Since this region is dominated by the ungrazed phytoplankton group with high DMSP content (van der Berg et al. 1996), increases in DMS production are higher along the coast than offshore. The model shows that the increase in DMS concentration does not lead to an equivalent increase in the sea-to-air flux. This is due to a shift in the relative importance of the loss terms for DMS, i.e. the exchange coefficient for DMS emission is independent of biological factors, whereas the concentration of bacteria increases in line with the increase in detrital matter. Thus, biological uptake of DMS becomes a relatively more important loss term. The increase in nutrients not only causes differential changes in DMS production on a spatial basis, but also in the temporal development of phytoplankton populations and DMS concentration. The spring bloom becomes relatively more important in DMS production than other periods of the year. This occurs because, although higher nutri- 

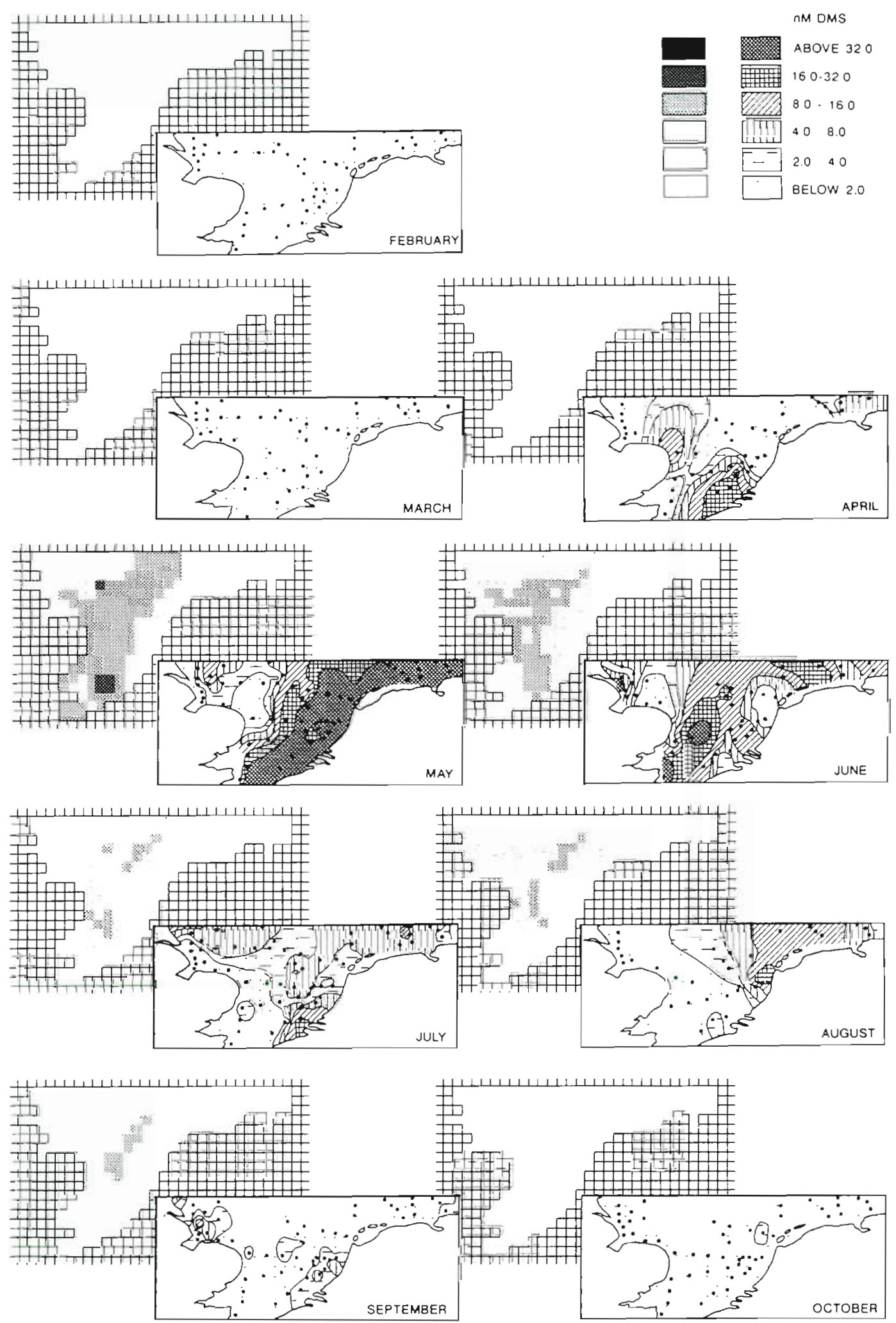

Fig. 8. Comparison of mean DMS concentrations at the beginning of the month for field data (overlay) and model (grid) results with grazed functional groups having high DMSP contents, in nmol $\mathrm{l}^{-1}$ (model variation B). Field data were collected by Turner et al. (1996) from. February to October 1989 
ents stimulate the production of all the phytoplankton groups, ungrazed phytoplankton groups with high DMSP become more dominant since the grazed phytoplankton species are suppressed by the zooplankton. Since lyase activity is associated with the ungrazed phytoplankton, relatively more DMS is produced via this pathway, as was the case for present-day simulation.

In summary, this is the first model which attempts to describe the spatial and temporal distribution of DMS in a very dynamic coastal system. The results indicate that it gives an adequate description of the DMS concentrations in the southern Vorth Sea. The indications are that lyase activity is an important process in DMS production and the sea-to-air release of DMS may not be neglected. Furthermore, it is necessary to define coastal species with high DMSP production rates and contents. Given this model, the DMS flux from sea to air can be calculated. It follows from the model that the anthropogenic nutrient input increased this flux $2 \frac{1}{2}$ times in the southern North Sea between the beginning of this century and the 1980s. This indicates that DMS has the potential to increase acidification of the air as a result of perturbation of natural processes.

Acknowledgements. We thank Jacqueline Stefels and the DMS-EU project members for their valuable discussions and comments on the model. This work was supported by the European Community, project contract EV 5V ("I93-0326.

\section{LITERATURE CITED}

Andreae MO (1990) Ocean-atmosphere interactions in the global biochemical sulfur cycle. Mar Chem 30:1-29

Andreae MO, Barnard WR, Ammons JM (1983) The biological production of dimethylsulphide in the ocean and its role in the global atmospheric sulphur budget. Ecol Bull 35: $167-177$

Ayers GP, Ivey JP, Gillet RW (1991) Coherence between seasonal cycles of dimethylsulphide methanaan sulphanaat and sulphate in marine air. Nature 349:404-406

Belviso S, Kim SK, Rassoulzadegan F, Krajka B, Nguyen BC, Mihalopoulos N, Buat-Menard P (1990) Production of dimethylsulfoniumpropionate (DMSP) and dimethylsulfide (DMS) by a microbial food web. Limnol Oceanogr 35: $1810-1821$

Billen G, Fontigny A (1987) Dynamics of a Phaeocystis-domunated spring bloom in Belgian coastal waters. II. Bacterioplankton dynamics. Mar Ecol Prog Ser 37:249-257

Billen G, Joiris C, Meyer-Reil L, Lindeboom H (1990) Role of bacteria in the North Sea ecosystem. Neth J Sea Res 26: 265-293

Brussaard CPD, Riegman R, Noordeloos AAM, Cadée GC, Witte H. Kop AJ, Nieuwland G, van Duyl FC: Bak RPM (1995) Effects of grazing, sedimentation and phytoplankton cell lysis on the structure of a coastal pelagic food web. Mar Ecol Prog Ser 123:259-271

Cadee GC (1990) Increased bloom. Nature 346:418

Cantonı GL, Anderson DG (1956) Enzymatic cleavage of dl- methylpropıthetin by Polysiphonia lanosa. J Biol Chem 222:171-177

Challenger F (1959) Aspects of the organic chemistry of sul tur. Academic Press, New York

Charlson RJ, Lovelock JE. Andreae MO, Warren SG (1987) Oceanic phytoplankton, atmospheric sulphur, cloud albedo and climate. Nature 326:655-661

Cooper WJ, Matrai PA (1989) Distribution of dimethylsulfide in the oceans. In: Saltzman E, Cooper W (eds) Biogenic sulfur in the environment. Symposium Series, Vol 393, American Chemical Society, Washington, p 140-151

Dacey JWH, Blough NV (1987) Hydroxide decompositton of DMSP to form DMS. Geophys Res Lett 14:1246-1249

Dacey JWH, Wakeham SG (1986) Oceanic dimethylsulfıde: production during zooplankton grazing on phytoplankton. Science 233:1314-1316

Dyer KR, Moffat TJ (1993) Suspended sediment distributions in the North Sea. Institute of Marine Studies Tech Rep. University of Plymouth, Devon, UK

Elsma D (1981) Supply and deposition of suspended matter in the North Sea. Spec Publs Int Assoc Sediment, Vol 5. Blackwell, Oxford, p 415-428

Estep KW, Nejstgaard JC, Skjoldal HR, Rey F (1990) Predation by copepods upon natural populations of Phaeocystis pouchetii as a function of the physiological state of the prey. Mar Ecol Prog Ser 67:235-249

Fransz HG, Gieskes WWC (1984) The unbalance of phytoplankton and copepods in the North Sea. Rapp PV Réun Cons Int Explor Mer 183:218-226

Gabric A, Murray N, Stone L, Kohl M (1993) Modeling the production of dimethylsulfide during a phytoplankton bloom. J Geophys Res 98:22805-22816

Hansen FC, Reckermann M, Klein Breteler WCM, Riegman R (1993) Phaeocystıs blooming enhanced by copepod predation on protozoa: evidence from incubation experiments Mar Ecol Prog Ser 102:51-57

Hansen FC, van Boekel WHM (1991) Grazing pressure of the calanoid copepod Temora longicornis on a Phaeocystis dominated spring bloom in a Dutch tidal inlet. Mar Ecol Prog Ser 78:123-129

Ishida Y (1968) Physiological studies on evolution of dimethylsulphide from unicellular marine algae. Mem Coll Agric Kyoto Univ $94: 47-82$

Iverson RL, Nearhoof FL, Andreae MO (1989) Production of dimethylsulfoniumproprionate and dimethylsulfide by phytoplankton in estuarine and coastal waters Limnol Oceanogr 34:53-67

Joint I, Pomroy A (1993) Phytoplankton biomass and production in the southern North Sea. Mar Ecol Prog Ser 99: $169-182$

Keller MD, Bellows WK, Guillard RRL (1989) Dimethylsulphide production in marine phytoplankton. In: Saltzman E, Cooper W (eds) Biogenic sulfur in the environment. Symposium Series, Vol 393, American Chemical Society, Washington, p 167-182

Kiene RP (1990) Dimethylsulfide production from dimethylsulfoniopropionate in coastal seawater samples and bacterial cultures. Appl Environ Microbiol 56:3292-3297

Kiene RP (1992) Dynamics of dimethylsulfide and dimethylsulfonıopropionate in oceanic water samples. Mar Chem $37: 29-52$

Kiene RP, Bates TS (1990) Biological removal of dimethylsulphide from seawater. Nature 345:702-705

Kiene RP, Service SK (1991) Decomposition of dissolved DMSP and DMS in estuarine waters: dependence on temperature and substrate concentration. Mar Ecol Prog Ser $76: 1-11$ 
KNMI (1991) NOAA satelite images. KNMI Tech Rep, Koninklijk Nederlands Meteorologisch Instıtuut, Ministerie van Verkeer en Waterstaat, De Bilt

Kwint RLJ, Irigoien X, Kramer KJM (1996) Copepods and DMSP, In: Kiene RP, Visscher PT, Keller MD, Kirst GO (eds) Biological and environmental chemistry of DMSP and related sulphonium compounds. Plenum Press, New York, p 239-254

Lancelot C, Billen G (1984) Activity of heterotrophic bacteria and its coupling to primary production during the spring bloom in the southern bight of the North Sea. Limnol Oceanogr 29:721-730

Lawrence $M$ (1993) An empirical analysis of the strength of the phytoplankton-dimethylsulfide-cloud-climate feedback cycle. J Geophys Res 98:20663-20673

Leck C, Larsson U, Bagander LE, Johansson S, Hadja S (1990) DMS in the Baltic Sea - annual variability in relation to biological activity. J Geophys Res 95:3353-3363

Leck C, Rodhe (1991) Emissions of marine biogenic sulfur to the atmosphere of northern Europe. J Atmos Chem 12:63-86

Liss PS, Malin G, Turner S, Holligan P (1994) Dimethylsulphide and Phaeocyst1s: a review. J Mar Syst (5):41-53

Liss PS. Slater PG (1974) Flux of gases across the air-sea interface. Nature 247:181-184

Liss PS, Watson AJ, Liddicoat MI, Malin G, Nightingale PD, Turner SM, Upstill-Goddard RC (1993) Trace gases and air-sea exchanges. Philos Trans R Soc Lond B Biol Sci 343: $531-541$

Malm G, Turner SM, Liss PS, Hollıgan PM, Harbour DS (1993) Dimethylsulphide and dimethylsulfoniopropionate in the North East Atlantic during the summer coccolithophore bloom. Deep Sea Res 40:1487-1508

Matrai PA, Keller MD (1994) Total organic sulfur and dimethylsulfoniopropionate in marine phytoplankton: intracellular variations. Mar Biol 119:61-68

NERC (1989) The North Sea project medsurements. CDROM, British Oceanographic Data Centre, Proudman Ocean Lab, Merseyside, UK

Stefels J. Dijkhuizen L, Gieskes WWC (1995) DMSP-lyase activity in a spring phytoplankton bloom off the Dutch coast, related to Phaeocystis sp. abundance. Mar Ecol Prog Ser 123:235-243

This article was submitted to the editor
Stefels J, van Boekel WHM (1993) Production of DMS from dissolved DMSP in axenic cultures of the marine phytoplankton species Phaeocysths sp. Mar Ecol. Prog Ser 97 : $11-18$

Taylor BF, Gilchrist DC (1991) New routes for aerobic biodegradation of dimethylsulfoniopropionate. Appl Environ Microbiol 57:3581-3584

Taylor BF, Kiene RP (1989) Microbial metabolısm of dimethylsulfide. In: Saltzman E, Cooper W (eds) Blogenic sulfur in the environment. Symposium Series, Vol 393, American Chemical Society, Washington, p 202-221

Turner SM, Malin G, Liss PS, Harbour DS, Holligan PM (1988) The seasonal variation of dimethylsulfide and dimethylsulfoniopropionate concentrations in nearshore waters. Limnol Oceanogr 33:364-375

Turner SM, Malin G, Nightingale PD, Liss PS (1996) Seasonal variation of dimethylsulphide in the North Sea and an assessment of fluxes to the atmosphere. Mar Chem $54(3 / 4): 245-262$

van Boekel WHM, Hansen FC, Riegman R, Bak RPM (1992) Lysis-induced decline of a Phaeocystis spring bloom and coupling with the microbial foodweb. Mar Ecol Prog Ser 81:269-276

van den Berg AJ, Ridderinkhof $H_{1}$, Riegman $R_{1}$ Ruardij $P_{\text {, }}$ Lenhart $H$ (1996) Influence of variability in water transport on phytoplankton biomass and composition in the southern North Sea: a modelling approach (FYFY). Cont Shelf Res 16:907-931

Visscher PT, Diaz MR, Taylor BF (1992) Enumeration of bacteria which cleave or demethylate dimethylsulfoniopropionate in the Caribbean Sea. Mar Ecol Prog Ser 89: 293-296

Wakeham SG. Howes BL, Dacey JWH, Schwarzenbach P, Zeyer J (1987) Biochemistry in a seasonally stratified coastal salt pond. Geochim Cosmochim Acta 51 $1675-1684$

Weisse T, Scheffel-Moser U (1990) Growth and grazing loss rates in single-celled Phaeocystis sp. (Prymnesiophyceae). Mar Biol 106:153-158

Wolfe GV, Sherr EB, Sherr BF (1994) Release and consumption of DMSP from Emiliania huxleyi dunng grazing by Oxyrrhis marina. Mar Ecol Prog Ser 111:111-120

Manuscript first received: March 28, 1996

Revised version accepted: September 3, 1996 